\title{
タイヤ添加剤の安定性と環境試料の分析法検討
}

\author{
三島 聡子, 田中 達也*, 北野 大* \\ 神奈川県環境科学センター（２２54-0014＼cjkstart神奈川県平塚市四之宮1-3-39） \\ *明治大学大学院 理工学研究科（†214-8571 神奈川県川崎市多摩区東三田1-1-1）
}

[平成24年 7 月 19 日受付, 平成25年 1 月 15 日受理］

\section{Studies on the Stability of Tire Rubber Additives and their Simultaneous Analysis in the Environmental Samples}

\author{
Satoko MISHIMA, Tatsuya TANAKA * and Masaru KITANO * \\ Kanagawa Environmental Research Center \\ (1-3-39 Shinomiya, Hiratsuka, Kanagawa 254-0014) \\ * Meiji Univercity \\ (1-1-1 Higashimita, Tama, Kawasaki, Kanagawa 214-8571)
}

[Received July 19, 2012; Accepted January 15, 2013]

\begin{abstract}
Summary
In recent years, adverse effects on the environment caused by the tire rubber additives listed up as PRTR chemicals has become a great concern. Therefore, it is important to evaluate the fate and behavior of these chemicals in the environment. In this study, the effects of analytical conditions on the stability and extraction recoveries of them in the environmental samples were investigated to establish simultaneous analytical methods of these compounds.

Four hour ultrasonic extraction bellow $40{ }^{\circ} \mathrm{C}$ was found effective to extract the tire rubber additives from tire rubber particles. Tire rubber additives contained in the atmosphere particles were stable after 4days aeration, their recovery rates were over $87 \%$. Dehydration of solid phase cartridges for the analysis of water samples by centrifuge was more effective than $\mathrm{N}_{2}$ gas purge method. In order to obtain sufficient recovery rates, water samples should be adjusted at $\mathrm{pH} 6 \sim$ 8 , preserved in cool and dark place and extracted on the sampling day. Both the recovery rates of tire rubber additives in pure and river water were over $85 \%$. Clean up with Florisil cartridge was necessary for the analysis of these chemicals in sediments by LC/MS/MS to get high peak intensity. The recovery rates of tire rubber additives in sediments were over $91 \%$.
\end{abstract}

Key words: tire rubber additives, PRTR chemicals, stability, simultaneous analysis, LC/MS/MS

\section{1.はじめに}

自動車交通は，自動車排気ガス及びタイヤ摩耗粉じん等を発生さ せることにより，環境大気及び河川水等の水質に影響を及ぼして いることが知られ，報告されている1-7)。神奈川県は，都道府県別・ 車種別自動車保有台数が平成 10 年度から平成 23 年度まで全国第 3 位以内であるため，特に自動車からの排出ガス等の影響について考 慮する必要がある。また, 平成 21 年 9 月から大気污染に係る環境 基準項目となった8) 微小粒子状物質（PM2.5）については, 発生源 や共存する化学物質について完全には明らかとはなっていないもの の，その生成要因の一つはタイヤ摩耗粉じんであると言われてい

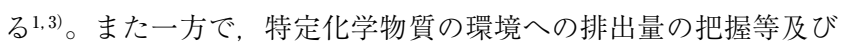
管理の改善の促進に関する法律（化管法）の対象物質9) は, その有 害性が懸念され7,10), 広範な地域の環境において検出されているか または恐れがあるものが選定されている。タイヤ添加剤の中でも，
化管法の対象となっている物質は, 環境への排出量が多く ${ }^{11)}$, ヒト や水生生物に影響する恐れがあり ${ }^{12-18)}$, 夕イヤ摩耗粉じんが大気中 や道路上に負荷した後, 降雨等により水域に負荷する等の環境動態 を把握する必要がある。このため, 様々な分析法の検討がなされ, 報告されている(19-26)。しかし, タイヤ添加剤個々, あるいは類似構 造の化合物群のみの分析法が多く，迅速な分析を行うためのこれら タイヤ添加剤の一斉分析法の報告例がほとんどない。また，タイヤ 添加剤には, 分析操作中に分解しやすい物質も存在し, 抽出等にお ける諸条件が回収率に影響する ${ }^{19-22)}$ 。そこで, 本研究では, 大気, 水質及び底質試料中に含まれるタイヤ添加剂についての一斉分析法 の検討を行い, 試料の性状や分析時の諸条件による夕イヤ添加剂の 安定性及び抽出効率の影響について明らかにした。 


\section{2. 方法}

\section{1 対象物質, 試薬及び分析条件}

本研究で対象としたタイヤ添加剤 8 物質の物性值及び藻類, ミジ ンコ, 魚類の水生生物の毒性值等を Table 1 に示す。この 8 物質は, 化管法で対象となっている夕イヤ添加剤等である。水生生物に対 する影響をみると、ジフェニルアミン (DPA), N-シクロヘキシル

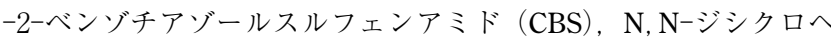
キシル-2-ベンゾチアゾールスルフェンアミド(DCBS) 及び N- (tertブチル)-2-ベンゾチアゾールスルフェンアミド（TBBS）について は藻類の慢性毒性值が， $\mathrm{N}$-ニトロソジフェニルアミン（NDPA）に ついてはミジンコの慢性毒性值が, N-1, 3-ジメチルブチル-N'-フェ ニル-p-フェニレンジアミン（DMPPD）については魚類の急性毒 性值が低いものでは $\mu \mathrm{g} / \mathrm{L}$ オーダーとなり，農薬のチウラムやオキ シン銅と同様にその影響が懸念されるため, 本研究における対象物 質とした。NDPA は米国 Accustandard 社製，DPA は関東化学社製， CBS, DCBS, 及びTBBS は和光純薬工業社製，N， N'-ジフェニ ル-p-フェニレンジアミン（DPPD）及び DMPPD は東京化成工業 社製， N,N-ジトリル-p-フェニレンジアミン（DTPD）については, 米国 Sigma-Aldrich 社製の標準品を使用した。また，内標準物質と して使用したDPPDの 10 箇所の水素が重水素で置換された安定同 位体の DPPD-d 10 は林純薬工業社製の分析用標準品を用いた。

各タイヤ添加剤標準液の調製, 抽出溶媒には関東化学社製のア セトン, メタノール及びジクロロメタン（残留農薬試験用）を用 いた。LC/MS/MSの溶離液に用いたメタノールは関東化学社製の LC/MS 用を, ぎ酸は関東化学社製の特級品を, 超純水は和光純薬 工業社製の PFOS·PFOA 分析用を使用した。

タイヤ粉じん中の夕イヤ添加剤の抽出条件の検討に使用した模擬 タイヤ粉じんは, 寿産業社製廃タイヤリサイクル微粉ゴムであり, 微粉にする際に薬品を加えていない, 平均粒径約 $300 \mu \mathrm{m}$ を使用し た。

タイヤ添加剤の分析は LC/MS/MS（Waters 社製 QuattroPremier XE）で行った。Table 2 にC/MS/MS 法による分析条件
及び本研究で使用した 4 種類の検量線について示す。分析をした媒 体によって, 含有する夕イヤ添加剤の量が様々なため, 分析の際に は適した検量線と LC/MS/MS 分析する最終液量を選択した。各夕 イヤ添加剤の検量線の決定係数 $\left(\mathrm{R}^{2}\right)$ は 0.984 から 1.00 と直線性 を示した。

\section{2 タイヤ粉じん中のタイヤ添加剤の抽出条件の検討}

大気粉じん中には, タイヤが摩耗して生じたタイヤ粉じんが含ま れており, 大気粉じん中の夕イヤ添加剤の分析において, タイヤ粉 じんの分析は重要である。そこで, タイヤ粉じん中のタイヤ添加剤 分析における抽出法, 抽出時間及び抽出溶媒等の抽出条件の検討を 行った。模擬夕イヤ粉じんをソックスレー抽出及び超音波照射下で の抽出を行った。抽出溶媒は, メタノール, アセトン及びジクロロ メタンを使用した。一定時間抽出後, 抽出液は窒素ガスパージで濃 縮してメタノールで定容し, DPPD-d 10 を添加し, LC/MS/MS で定 量した。

\section{3 大気試料中のタイヤ添加剤の捕集及び分析法の検討}

大気及び大気粉じんに含まれるタイヤ添加剂の捕集時の安定性に ついて検討した。大気試料については石英纎維ろ紙または活性炭 ディスクにタイヤ添加剤標準品を添加して PCI サンプラー（東京ダ イレック社製）に装着し，一定期間，環境大気を通気した。大気粉 じんについては模擬タイヤ粉じんまたは捕集済み大気粉じんを石英 纎維ろ紙に載せ, PCI サンプラーに装着し, 一定期間, 環境大気を 通気した。通気後の石英繊維ろ紙, 活性炭ディスク, 模擬夕イヤ粉 じん及び捕集済み粉じんは, メタノールによる超音波照射下での抽 出を 4 時間行った後, 窒素ガスパージで濃縮, 石英纎維ろ紙でろ過 し, メタノールで定容後, DPPD-d 10 を添加し, LC/MS/MS で定量 した。

\section{4 水質試料中のタイヤ添加剤の抽出法の検討}

固相抽出法による水質試料中の夕イヤ添加剤の分析法を検討し た。検討した抽出条件を Table 3 に示す。アセトン $10 \mathrm{~mL}$, メタノー

Table 1 Tire rubber additives in this study

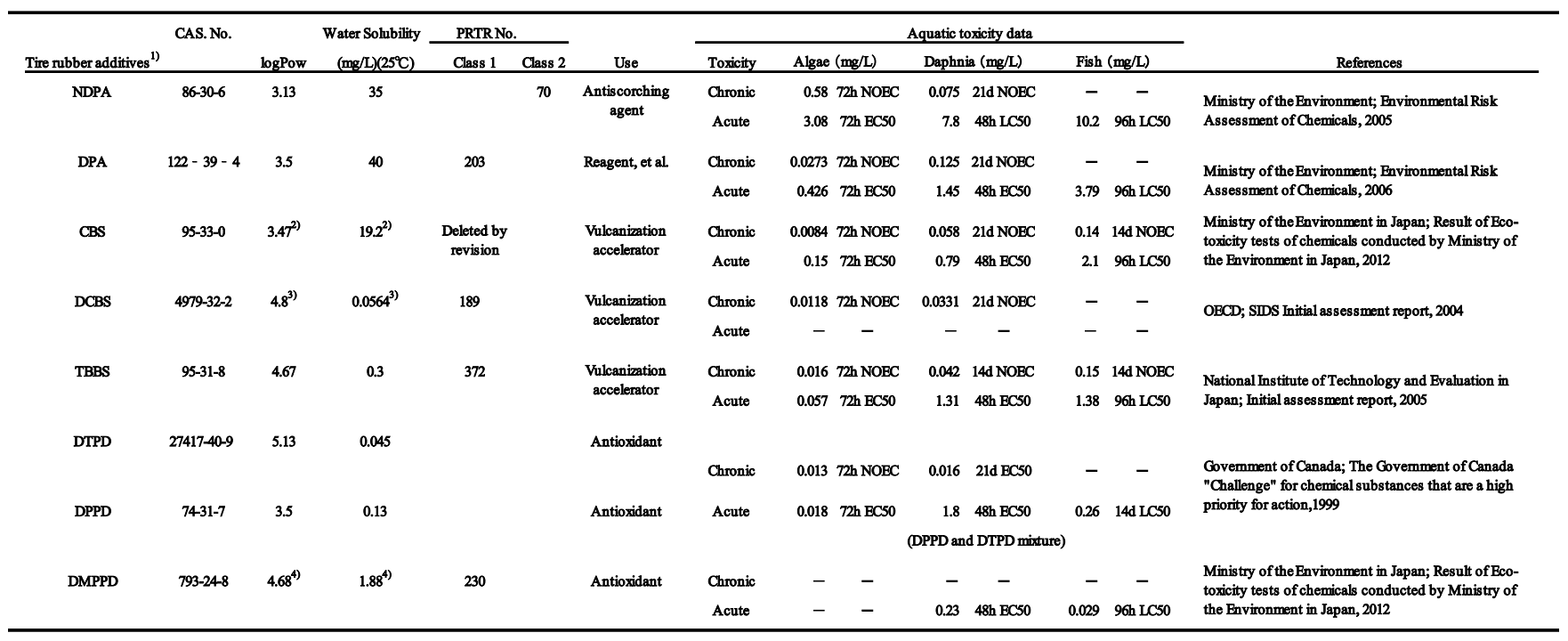

1) NDPA: N-Nitrosodiphenylamine, DPA: Diphenylamine, CBS: N-Cyclohexyl-2-benzothiazolesulfenamide, DCBS: N,N-Dicyclohexyl-2-benzothiazolesulfenamide, TBBS: $\mathrm{N}$-(tert-Butyl)-2-benzothiazolesulfenamide,

DTPD: N,N-Ditolyl-1,4-phenylenediamine, DPPD: N,N-Diphenyl-1,4-phenylenediamine, DMPPD: N-(1,3-Dimethylbutyl)-N-phenyl-1,4-phenylenediamine

2) Ministry of the Environment; Environmental Risk Assessment of Chemicals, 2006

3) Ministry of the Environment; Environmental Risk Assessment of Chemicals, 2010

4) Ministry of the Environment; Environmental Risk Assessment of Chemicals, 2010 
Table 2 Operation conditions for LC/MS/MS

\begin{tabular}{|c|c|c|c|c|c|c|c|c|c|}
\hline \multicolumn{10}{|c|}{ (1) HPLC conditions (Acquity UPLC ${ }^{\mathrm{TM}}$ ) } \\
\hline Column & \multicolumn{9}{|c|}{$\begin{array}{c}\text { Acquity UPLC }{ }^{\oplus} \text { BEH C18 } \\
(1.7 \mu \mathrm{m} 2.1 \mathrm{~mm} \times 50 \mathrm{~mm})\end{array}$} \\
\hline Mobile phase & \multicolumn{9}{|c|}{$\mathrm{A}:$ Water (pH 3.5 with formic acid) } \\
\hline Gradient & \multicolumn{9}{|c|}{$90 \% \mathrm{~A}(0.5 \mathrm{~min})$-(linear gradient $5 \mathrm{~min})-90 \% \mathrm{~B}(3 \mathrm{~min})$} \\
\hline Flow & \multicolumn{9}{|c|}{$200 \mu \mathrm{L} / \min$} \\
\hline Oven temperature & \multicolumn{9}{|l|}{$40{ }^{\circ} \mathrm{C}$} \\
\hline Injection volume & \multicolumn{9}{|l|}{$10 \mu \mathrm{L}$} \\
\hline \multicolumn{10}{|c|}{ (2) MS/MS conditions (Quattro-Premier XE) } \\
\hline Ionization mode & \multicolumn{9}{|c|}{ Positive-ESI } \\
\hline Capillary voltage & \multicolumn{9}{|c|}{$3 \mathrm{kV}$} \\
\hline Ion source temperature & \multicolumn{9}{|l|}{$120^{\circ} \mathrm{C}$} \\
\hline Desolvation temperature & \multicolumn{9}{|l|}{$450{ }^{\circ} \mathrm{C}$} \\
\hline Desolvation gas & \multicolumn{9}{|l|}{$900 \mathrm{~L} / \mathrm{hr}$} \\
\hline Cone gas & \multicolumn{9}{|l|}{$50 \mathrm{~L} / \mathrm{hr}$} \\
\hline Collision gas & \multicolumn{9}{|l|}{$0.3 \mathrm{~mL} / \mathrm{min}$} \\
\hline \multirow[t]{2}{*}{ (3) MRM monitor ion } & \multirow[b]{2}{*}{ MW } & Precursor ion & \multirow{2}{*}{$\begin{array}{l}\text { Cone } \\
\text { energy } \\
\text { (V) }\end{array}$} & \multirow{2}{*}{$\begin{array}{c}\text { Product ion } \\
(\mathrm{m} / \mathrm{Z}) \\
\end{array}$} & \multirow{2}{*}{$\begin{array}{c}\text { Collision } \\
\text { energy } \\
\text { (V) }\end{array}$} & \multicolumn{3}{|c|}{$\mathrm{R}^{2}$ of standard solution ${ }^{*}$} & \multirow[b]{2}{*}{ St. 4} \\
\hline & & $(\mathrm{m} / \mathrm{Z})$ & & & & St. 1 & St. 2 & St. 3 & \\
\hline NDPA & 198.2 & 198.8 & 16 & 168.8 & 12 & 0.996 & 1.00 & 0.994 & 0.996 \\
\hline DPA & 169.2 & 169.8 & 30 & 92.5 & 24 & 0.991 & 0.995 & 0.995 & 0.994 \\
\hline CBS & 264.4 & 264.8 & 18 & 182.5 & 12 & 0.984 & 0.999 & 1.00 & 0.987 \\
\hline DCBS & 346.6 & 347.0 & 24 & 180.0 & 24 & 0.996 & 0.997 & 0.994 & 0.985 \\
\hline TBBS & 238.4 & 238.8 & 18 & 182.6 & 14 & 0.992 & 0.999 & 0.998 & 0.995 \\
\hline DTPD & 288.3 & 289.3 & 36 & 198.1 & 24 & 0.990 & 1.00 & 0.994 & 0.998 \\
\hline DPPD & 260.3 & 261.3 & 34 & 184.1 & 24 & 0.984 & 1.00 & 0.998 & 0.998 \\
\hline DMPPD & 268.4 & 269.3 & 22 & 184.3 & 28 & 0.992 & 0.990 & 0.998 & 0.995 \\
\hline DPPD-d $_{10}$ (Internal standard) & 270.3 & 271.3 & 36 & 189.2 & 24 & & & & \\
\hline
\end{tabular}

${ }^{*}$ St.1: Standard solution of $5,10,20,50,100 \mathrm{ng} / \mathrm{mL}$.

St.2: Standard solution of $0.1,0.2,0.5,1,2,5,10 \mathrm{ng} / \mathrm{mL}$.

St.3: Standard solution of $0.05,0.1,0.2,0.5,1,2 \mathrm{ng} / \mathrm{mL}$.

St.4: Standard solution of $0.01,0.02,0.05,0.1,0.2 \mathrm{ng} / \mathrm{mL}$.

Table 3 Extraction conditions

\begin{tabular}{lccc}
\hline & Solid phase & Dehydration method & Extractant \\
\hline Condition 1 & Sep-Pak PS-2 & Nitrogen gas purge & Methanol \\
Condition 2 & Sep-Pak PS-2 & Centrifugal separation & Methanol \\
Condition 3 & Sep-Pak PS-2 & Centrifugal separation & Methanol+Acetone \\
Condition 4 & Presep ${ }^{\circledR}$-Agri & Centrifugal separation & Methanol+Acetone \\
\hline
\end{tabular}

ル $10 \mathrm{~mL}$ 及び超純水 $10 \mathrm{~mL}$ で洗浄及びコンディショニングした固 相カートリッジ, Sep-Pak PS-2 (Waters 社製) 及び Presep® -Agri (和 光純薬工業 (株) 製) を用い, 水質試料 $200 \mathrm{~mL}$ を $10 \mathrm{~mL} / \mathrm{min}$ の速 度で通水した。試料通水後のガラス容器の壁面を, 超純水約 $5 \mathrm{~mL}$ で 2 回洗浄してカートリッジに通水後, 20 分間の窒素ガスパージ あるいは遠心分離によりカートリッジを脱水し，メタノール及びア セトン $5 \mathrm{~mL}$ で溶出した。溶出液は, 窒素ガスパージ濃縮後, メ夕 ノールで定容し， DPPD-d 1 $_{10}$ を添加し， LC/MS/MS で定量した。

\section{5 底質及び土壤試料中のタイヤ添加剤の抽出法の検討}

乾泥 $10 \mathrm{~g}$ を大気粉じんと同様にメタノール超音波照射下での抽 出をし， 15 分間の遠心分離後，窒素ガスパージで $1 \mathrm{~mL}$ に濃縮， へ キサン $5 \mathrm{~mL}$ を添加後，無水硫酸ナトリウムで脱水，石英緘維ろ 紙でろ過して，窒素ガスパージで濃縮，ヘキサン $1 \mathrm{~mL}$ に転溶し た。へキサン溶液はクリーンアップ法を検討した。Sep-Pak フロリ ジルカートリッジカラム（Waters 社製，充填量 $910 \mathrm{mg}$ ）または,
Sep-Pak シリカゲルカートリッジカラム（Waters 社製，充填量 $1 \mathrm{~g}$ ) に試料溶液を添加し、ヘキサン $2 \mathrm{~mL}$ で洗浄, ヘキサン $5 \mathrm{~mL}$ (Fr.1), 20 \%アセトン/ヘキサン $10 \mathrm{~mL}$ (Fr.2)，40％アセトン/ヘキサン

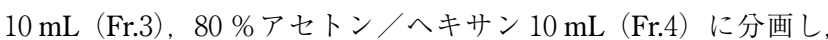
各分画を窒素ガスパージで濃縮, メ夕ノールで定容後, DPPD-d $\mathrm{d}_{10}$ を添加し，LC/MS/MSで定量した。

\section{3. 結果と考察}

\section{1 タイヤ粉じん中のタイヤ添加剤の抽出法及び諸条件における 安定性}

模擬タイヤ粉じん $0.02 \mathrm{~g}$ について, ジクロロメタンによる $60{ }^{\circ} \mathrm{C}$ でのソックスレー抽出及びメタノール，ジクロロメタン $20 \mathrm{~mL}$ 用いた $40{ }^{\circ} \mathrm{C}$ 以下での超音波照射下の抽出をした。ジクロロメ夕 ン溶液は, メタノールに転溶し，メタノール溶液に DPPD- $\mathrm{d}_{10}$ を $50 \mathrm{ng}$ 添加し, LC/MS/MS で定量した。ソックスレー抽出結果を Fig. 1 （a）に，超音波照射下の抽出結果を Fig. 1（b）に示す。模 擬タイヤ粉じんからは主にCBS と DMPPD が検出されたが，これ らのジクロロメタンによる抽出を比べると、超音波照射下が明らか に高い濃度を示している。同じ抽出時に $60{ }^{\circ} \mathrm{C}$ で加熱操作を行うソッ クスレー抽出法では，加熱分解が生じたために抽出率が低下したも のと考えられる。また，CBS 等のスルフェンアミド系加硫促進剤 については，加熱分解性が報告されている27)。そこで，対象とした 物質の温度に対する分解性を確認した。各夕イヤ添加剂標準物質 $1000 \mathrm{ng}$ をジクロロメタン $20 \mathrm{~mL}$ に添加し，10，20，30，40，50， 


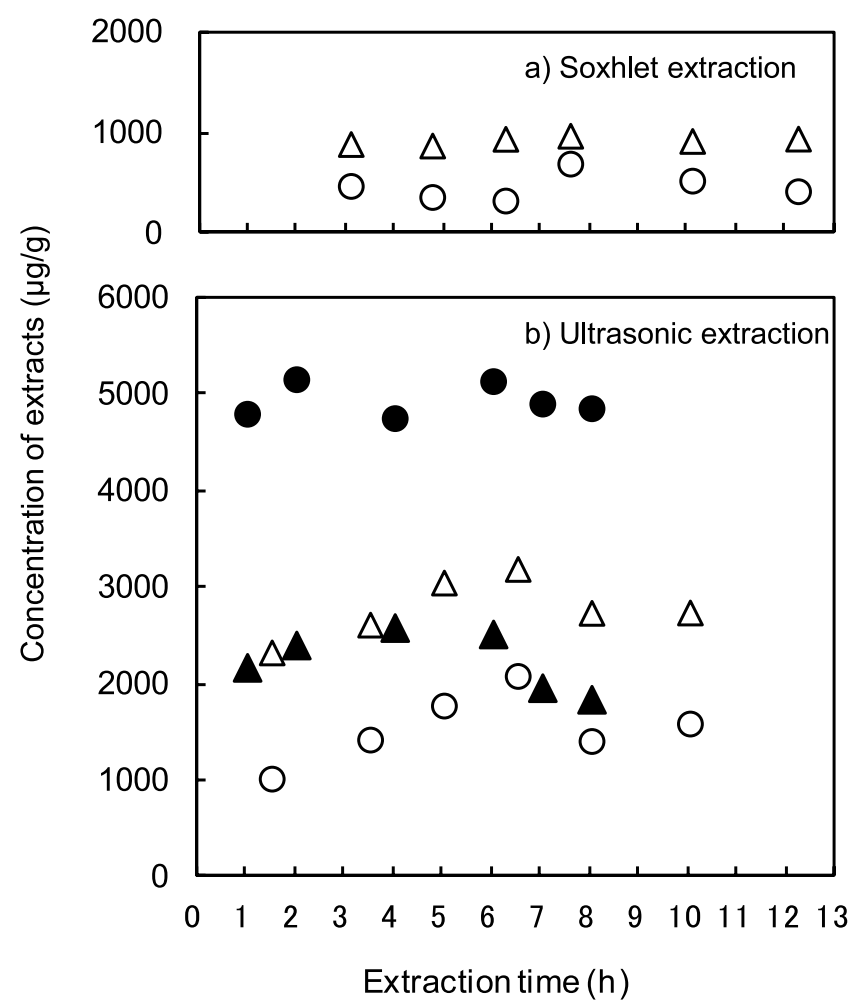

Fig. 1 Effect of extraction time on the extraction concentration of $(\bigcirc)$ CBS with dichoromethane, $(\triangle)$ DMPPD with dichoromethane, ( $)$ CBS with methanol, ( $\triangle$ ) DMP$\mathrm{PD}$ with methanol by (a) soxhlet extraction at $60{ }^{\circ} \mathrm{C}$, (b) ultrasonic extraction bellow $40{ }^{\circ} \mathrm{C}$

55 及び $60{ }^{\circ} \mathrm{C}$ の湯浴中に 1 時間静置した。ジクロロメタン溶液は, メタノールに転溶後 DPPD-d $\mathrm{d}_{10}$ を $50 \mathrm{ng}$ 添加し, LC/MS/MS で定 量した。その結果を Fig. 2 に示す。 $40{ }^{\circ} \mathrm{C}$ 超えると, タイヤ添加

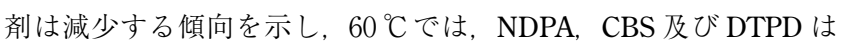
80 \%以下となった。そこで, 夕イヤ粉じん中のタイヤ添加剤の抽 出方法は, 加温を必要としない超音波照射下での抽出とし, 抽出時 には水槽の水温が $40^{\circ} \mathrm{C}$ 以上に上昇しないように超音波照射装置の 水槽の水を換水することとした。

また, Fig. 1（b）に示したように, 超音波照射下における抽出時 間と抽出された模擬夕イヤ粉じん中のタイヤ添加剤濃度の関係につ いては，抽出時間 4 時間までは，時間とともに高くなるが， 4 時間 を超えるとDMPPD の濃度が低下した。そこで，各標準物質のメ タノール溶液に対して超音波照射下での抽出時の安定性を確認し た。各タイヤ添加剤標準物質 $1000 \mathrm{ng}$ をメタノール $20 \mathrm{~mL}$ に添加し, 超音波照射下，一定時間ごとに抽出液を分取し，DPPD-d $\mathrm{d}_{10}$ を $50 \mathrm{ng}$ 添加し, LC/MS/MSで定量を行った。その結果を Fig. 3 に示す。 抽出時間が 4 時間を超えると TBBS 及び DMPPD 等, 減少する物 質が認められた。これらの物質においては, 超音波照射下での抽出 時間が一定の時間を超えると, 抽出量の増加よりも分解量の方が多 くなるものと考えられる。よって, 超音波照射下での抽出時間は模 擬夕イヤ粉じん中のタイヤ添加剂の濃度が最も大きかった 4 時間と した。次に, メタノール，アセトン及びジクロロメタンの抽出溶媒 について比較した。その結果を Fig. 4 に示す。ジクロロメタンによっ て抽出した CBS の濃度は, メタノール及びアセトンの場合の半分 に満たなかった。メタノール及びアセトンの抽出効率はほとんど同 様であったが, LC/MS/MS 分析時にはメタノールで定容する必要 があるため, タイヤからの抽出溶媒にはメタノールを用いることと

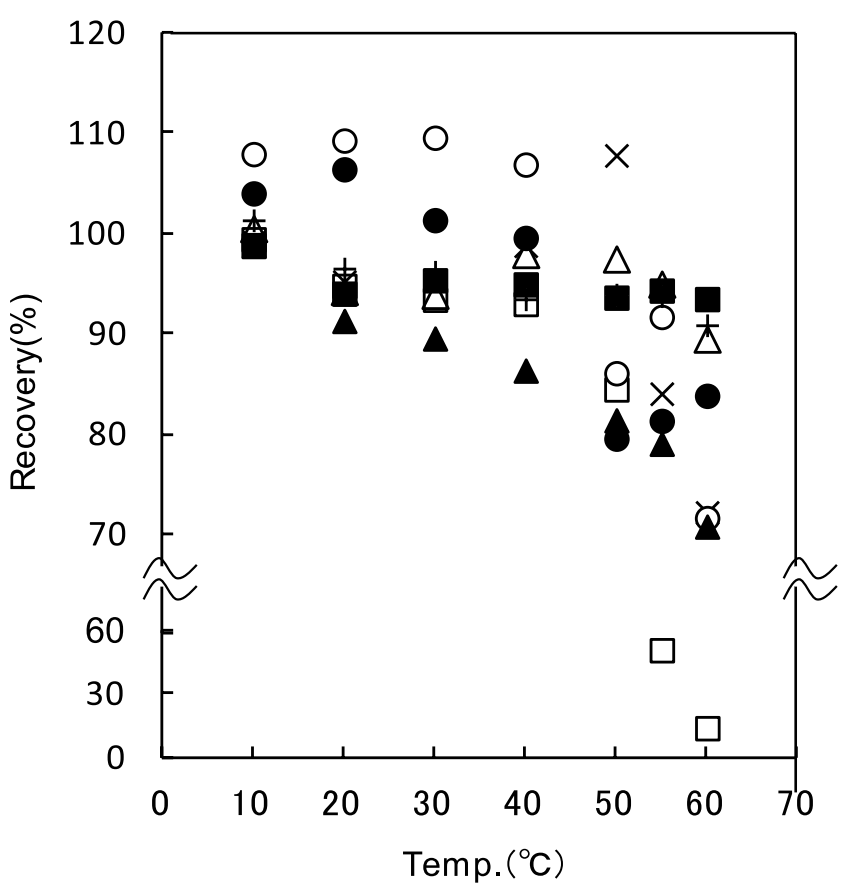

Fig. 2 Effect of temperature on the stability of $(\square)$ NDPA, $(\times)$ DPA, ( $\bigcirc$ ) CBS , ( $)$ DCBS, $(\boldsymbol{\square})$ TBBS, ( $\boldsymbol{\Delta}$ )DTPD, $(+)$ DPPD, $(\triangle)$ DMPPD after $1 \mathrm{~h}$

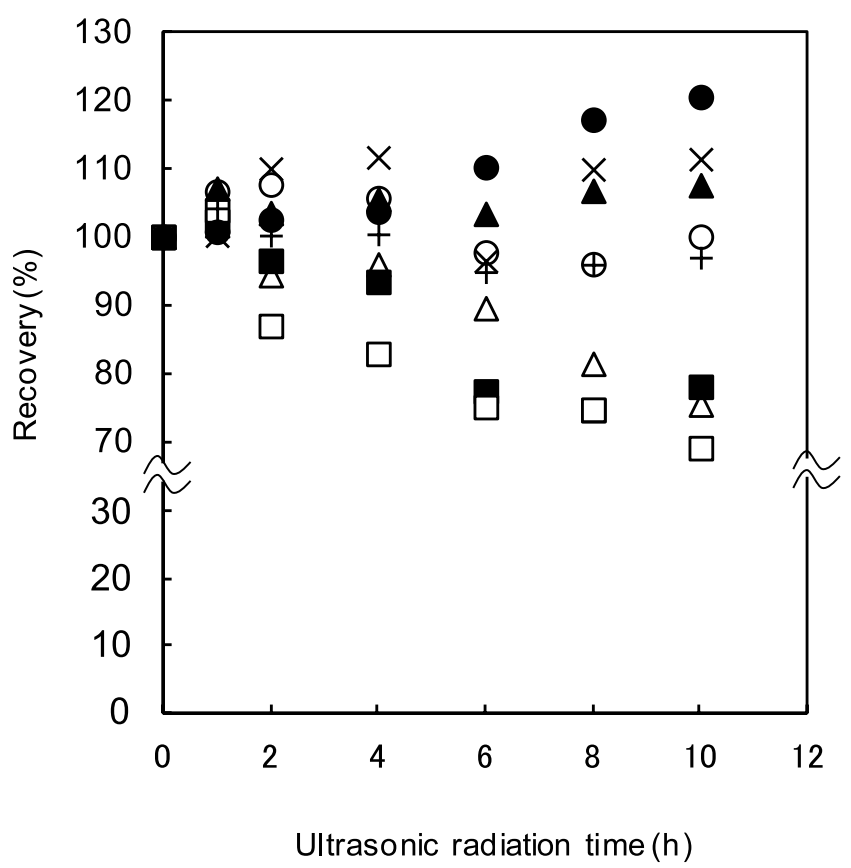

Fig. 3 Effect of ultrasonic radiation time on the stability of $(\square)$ NDPA, $(\times)$ DPA, $(\bigcirc)$ CBS, $(\bullet$ )DCBS, $(\boldsymbol{\square})$ TBBS, $(\boldsymbol{\Delta})$ DTPD, $(+)$ DPPD, $(\triangle)$ DMPPD with methanol

した。以上の結果から, 本研究における夕イヤ粉じん中の夕イヤ添 加剂の抽出法は, $40{ }^{\circ} \mathrm{C}$ 以下でのメタノール $20 \mathrm{~mL}$ による 4 時間超 音波照射下での抽出とした。

\section{2 大気試料中タイヤ添加剤の捕集法及び通気時の安定性 \\ 大気試料中の夕イヤ添加剤の捕集法を検討した。活性炭乃紙ディ スクまたは石英繊維ろ紙上にタイヤ添加剂標準品を $200 \mathrm{ng}$ 添加し}




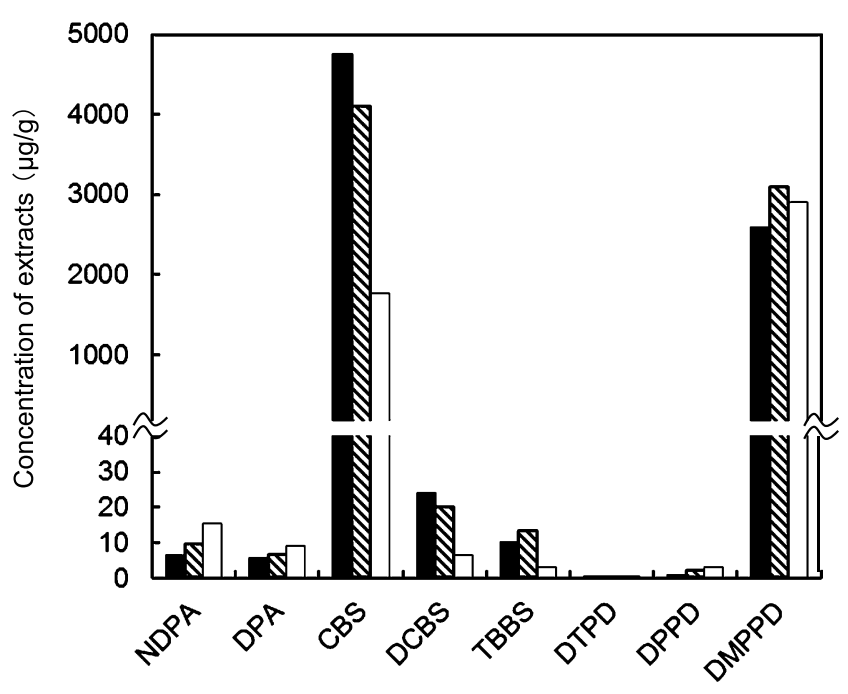

Fig. 4 Concentration of tire rubber additives extracted with ( methanol, ( $\mathbb{Q}$ ) acetone, ( $\square$ ) dichoromethane under ultrasonic radiation for $4 \mathrm{~h}$

て PCI サンプラーに装着し, 活性炭ろ紙ディスクは流量 $5 \mathrm{~L} / \mathrm{min}$, 石英繊維乃紙は流量 $20 \mathrm{~L} / \mathrm{min}$ で 24 時間通気した。通気後の活性炭 ろ紙ディスク及び石英繊維ろ紙は，3.1節において確立したタイヤ 粉じん中の夕イヤ添加剂の抽出法, $40{ }^{\circ} \mathrm{C}$ 以下のメ夕ノール $20 \mathrm{~mL}$ による 4 時間超音波照射下での抽出をし，窒素ガスパージで濃縮, 石英繊維万紙でろ過し，メタノールで定容後， DPPD-d d $_{10}$ を $50 \mathrm{ng}$ 添加して LC/MS/MS で定量した。24 時間通気した後は, 対象と した全てのタイヤ添加剤の回収率は $1 \%$ 未満となった。

次に，抽出操作における回収率を確認した。石英繊維ろ紙上に夕 イヤ添加剂標準品を $1 \mathrm{ng}$ 及びサロゲート内標準 DPPD-d 10 を $1 \mathrm{ng}$ 添加し，3.1節において確立したタイヤ粉じん中のタイヤ添加剤の 抽出法, $40{ }^{\circ} \mathrm{C}$ 以下のメタノール $20 \mathrm{~mL}$ による 4 時間超音波照射下 での抽出をし，窒素ガスパージで濃縮，石英繊維ろ紙でろ過し，メ タノールで $1 \mathrm{~mL}$ に定容後 LC/MS/MS で定量した。結果を Table 4 の左欄に示す。全てのタイヤ添加剤について，回収率 $92 \%$ 以上で

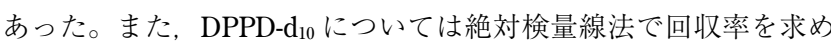
たところ，92\%であった。各夕イヤ添加剤及び DPPD-d ${ }_{10}$ の検量線 の決定係数 $\left(\mathrm{R}^{2}\right)$ は 0.991 から 1.00 と直線性を示した。これらの ことから, 大気と接触させると, タイヤ添加剤が分解すると考えら

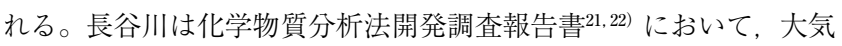
中の DTPD, DPPD 及びDMPPD の分析法を検討し，大気中では， これらのタイヤ添加剤が速やかに分解するが，粉じん中に存在する ものについては, 分析, 定量出来ることを明らかにしたが, 本研究 においても，同様の結果が得られた。

そこで次に, タイヤ摩耗粉じん中のタイヤ添加剤の通気時の安定 性について検討した。0.02 g の模擬タイヤ粉じんを石英繊維ろ紙 に載せ， $1 ， 2$ 及び 4 日間 PCI サンプラーにより環境大気を通気し， 3.1 節において確立したタイヤ粉じん中のタイヤ添加剤の抽出法, $40{ }^{\circ} \mathrm{C}$ 以下のメタノール $20 \mathrm{~mL}$ による 4 時間超音波照射下での抽出 をし，LC/MS/MS で定量した。1，2 及び 4 日間環境大気を通気し た後の模擬タイヤ粉じん中タイヤ添加剤含有量と環境大気を通気し ない 0 日目の含有量との比を Fig. 5 (a) に示す。対象とした夕イ ヤ添加剤全てについて，4 日間環境大気を通気した模擬タイヤ粉じ ん中の含有量は, 環境大気を通気しない模擬夕イヤ粉じん中の含有 量の $87 \%$ 以上であった。

また, 大気粉じん中のタイヤ添加剤の通気時の安定性について検
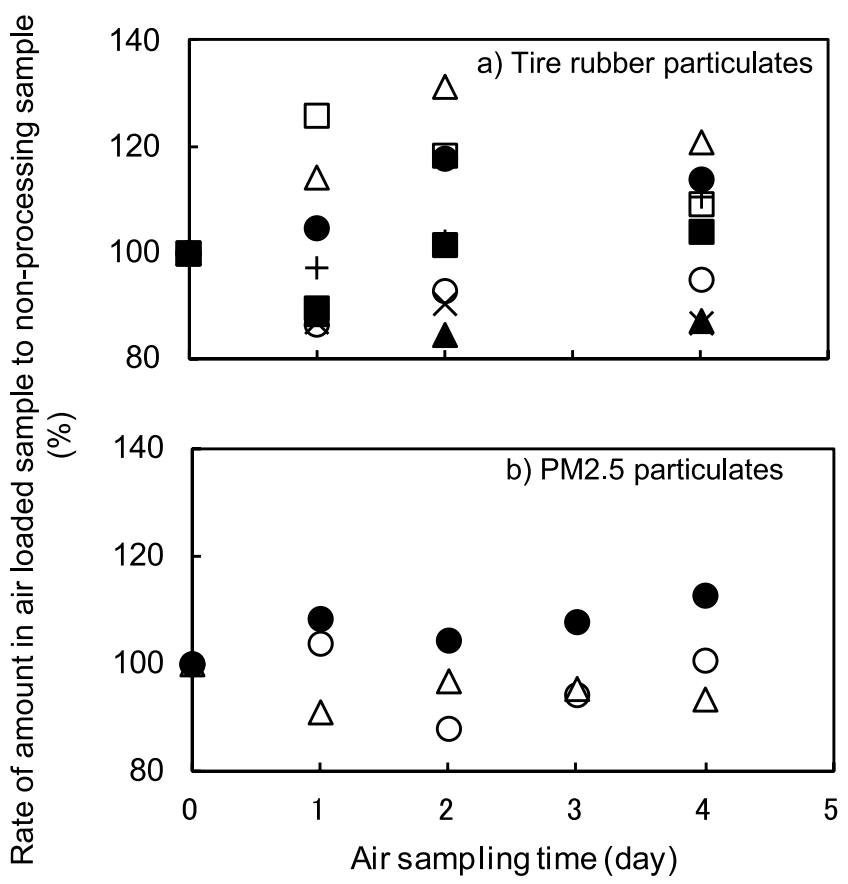

Fig. 5 Effects of aeration time on the stability of ( $\square$ ) NDPA, $(\times)$ DPA, $(\bigcirc)$ CBS, $(\bullet)$ DCBS, $(\boldsymbol{\square}) \mathrm{TBBS},(\boldsymbol{\Delta})$ DTPD, $(+)$ DPPD, $(\triangle)$ DMPPD in (a) tire rubber particles, (b) PM2. 5 particulates

討した。PCI サンプラーによって粒径 $2.5 \mu \mathrm{m}$ 以下を 1 日サンプリ ングした石英繊維ろ紙 6 枚を 6 等分し，各 6 等分を 1 枚ずつ， 6 枚 を石英纎維ろ紙に載せ，PCI サンプラーで $1 ， 2 ， 3$ 及び 4 日間通気 した。通気は, 他の粉じんが混入しないように, 出入口に前室を含 む 2 重扉構造があり, 給気・排気はプレフィルター, 活性炭フィ ルター, HEPAフィルターを通じる室内でおこなった。通気後, サ ロゲート内標準として DPPD-d 10 を $1 \mathrm{ng}$ 添加し，3.1節において確 立したタイヤ粉じん中のタイヤ添加剤の抽出法, $40{ }^{\circ} \mathrm{C}$ 以下のメ夕 ノール $20 \mathrm{~mL} に よ る 4$ 時間超音波照射下での抽出をし, 窒素ガス パージで濃縮，石英繊維ろ紙でろ過し，メタノールで $1 \mathrm{~mL}$ に定容， LC/MS/MS で定量した。1，2，3 及び 4 日間環境大気を通気した 後のタイヤ添加剤含有量と環境大気を通気しない 0 日目の含有量の 比を Fig. 5 （b）に示す。大気粉じんからは, 対象としたタイヤ添 加剤のうち, CBS, DMPPD 及び DCBS が検出され, 4 日間環境大 気を通気した大気粉じん中の夕イヤ添加剤は, 環境大気を通気しな い大気粉じん中の含有量の $94 \%$ 以上であった。このことから，粉 じん中のタイヤ添加剤は直接空気に触れないため, 分解されにくい ことが確認された。タイヤ添加剤は, その物質自身が分解すること でタイヤの品質の劣化を防ぐという機能を有しているために, 大気 中では夕イヤ添加剂に酸化分解が生じ, 捕集を難しくしているが, 直接空気に触れない粉じん中の夕イヤ添加剂は，4 日間環境大気を 通気しても分解することなく捕集することが可能であることがわ かった。

\section{3 水質試料中のタイヤ添加剤抽出法及び諸条件における安定性}

固相抽出による水質試料中の夕イヤ添加剤の分析法に打ける抽 出条件の影響について検討した。まず, 脱水方法について検討し た。固相は, Sep-Pak PS-2 を用い, タイヤ添加剂 $200 \mathrm{ng}$ を超純水 $200 \mathrm{~mL}$ に添加した水質試料を通水した後, 窒素ガスパージによる 脱水法 (Table 3 Condition (1)), および遠心分離による脱水法 (Table 3 Condition (2)）によって脱水し, $5 \mathrm{~mL}$ メタールで溶出した。溶 
出液は, 窒素ガスパージ濃縮後, メタノールで定容し, DPPD-d $\mathrm{d}_{10}$ を $50 \mathrm{ng}$ 添加し, LC/MS/MS で定量した。結果を Fig. 6 (a) に示す。 窒素ガスパージによる脱水法と遠心分離による脱水法について回収 率を比べると, NDPA及びDPAを除いて, 遠心分離による回収率 が高かった。窒素パージによる脱水法では, 大量の空気との接触に よって添加剤が分解したと推測される。NDPA 及びDPAの回収率 が低下したことについては，固相が完全に乾燥されずメタノールと 水が混合し, 溶出力が低下したためと考えられる。

そこで, 窒素ガスパージによる脱水の際のタイヤ添加剤の分解 性について確認した。コンディショニング及び遠心分離したカー トリッジに各タイヤ添加剤標準物質 $10 \mathrm{ng}$ を直接添加し, 窒素ガス パージによる脱水をしてメタノール $5 \mathrm{~mL}$ 及びアセトン $5 \mathrm{~mL}$ で溶 出した回収率及び窒素ガスパージによる脱水をしないでメタノール $5 \mathrm{~mL}$ 及びアセトン $5 \mathrm{~mL}$ で溶出した回収率を比較した。その結果 を Fig. 6 （b）に示す。窒素ガスパージによる脱水をしないでメ夕 ノールで溶出した方は，91\%以上の回収率を保ったが，窒素ガス パージによる脱水をしてメタノールで溶出した場合は, DCBSを除 いて, 回収率は 69 \%以下であった。以上の結果から, 以降の実験 では, 固相の脱水法には遠心分離を用いることとした。併せて, 窒 素ガスパージ濃縮の際にも, ガラス容器壁面のタイヤ添加剤が乾燥 により分解しないようにメタノールで洗い落とし, 乾固しないよう にした。

次に, タイヤ添加剂 $200 \mathrm{ng}$ を超純水 $200 \mathrm{~mL}$ に添加, Sep-Pak PS-2またはPresep®-Agriにより固相抽出し, 遠心分離及びメ夕 ノール $5 \mathrm{~mL}$ で溶出した後, 溶出力の強いアセトン $5 \mathrm{~mL}$ で溶出 (Condition (3)及びCondition (4)), その結果を Fig. 7 に示す。メタノー ルのみの溶出と比較して, メタノール及びアセトンを使用した方が 高い回収率が得られた。アセトンで溶出したため, メタノールのみ では溶出できなかった物質を溶出することができ, 全体の回収率が 向上したと考えられる。固相にPresep® -Agri を使用した場合は, Sep-Pak PS-2 を使用した場合よりも，対象としたほとんどのタイ ヤ添加剤について回收率が高く, 85 \%以上の回収率が得られた。

また，夕イヤ添加剤の中には，DCBSのように $\log$ Pow が4.8,

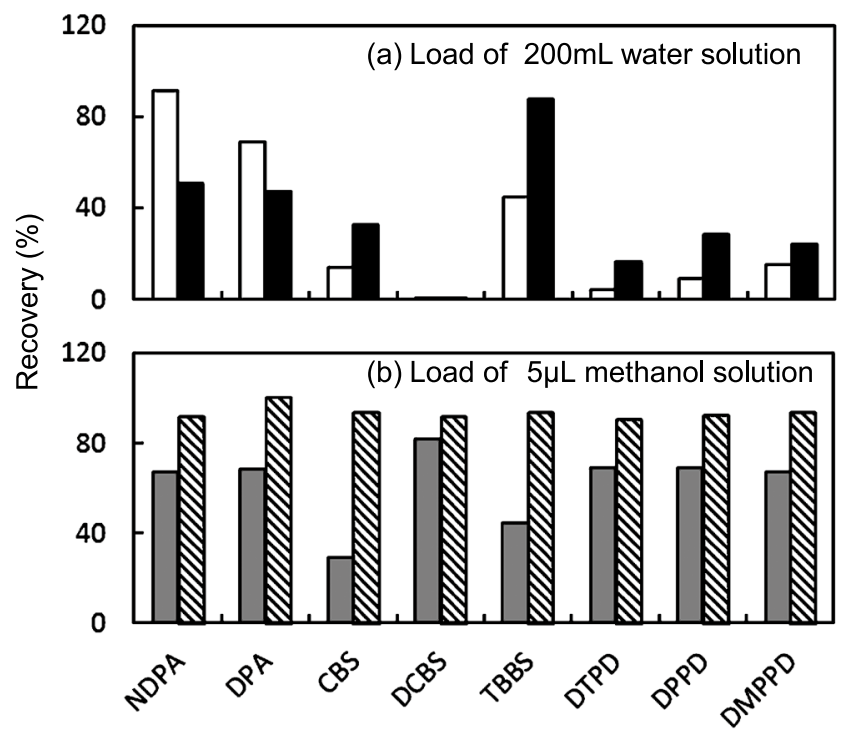

Fig. 6 Changes of recovery rates of tire rubber additives by the dehydration process with ( $\square$ ) $\mathrm{N}_{2}$ purge, ( $\mathbf{\square}$ ) centrifuge for (a) load of $200 \mathrm{~mL}$ water solution, ( $\square$ ) with $\mathrm{N}_{2}$ purge, ( $\mathbb{\mathbb { N }}$ ) without $\mathrm{N}_{2}$ purge for (b) load of $5 \mu \mathrm{L}$ methanol solution
水溶解度が $0.0564 \mathrm{mg} / \mathrm{L}$ と, 疎水性が高い物質もあるので, ガラ 久容器壁面への吸着性について検討した。試料を固相抽出, ガラス 容器を水洗後, ガラス容器壁面に吸着したまま残存したタイヤ添 加剂をメタノールで洗浄, LC/MS/MS で定量した。タイヤ添加剂 $200 \mathrm{ng}$ を超純水 $200 \mathrm{~mL}$ に添加した, 濃度が $0.001 \mathrm{mg} / \mathrm{L}$ の水溶液 の場合には, 検討したタイヤ添加剤全てについて全体の $3 \%$ 未満で あったが, タイヤ添加剂 $1 \mathrm{ng}$ を超純水 $200 \mathrm{~mL}$ に添加した, 濃度が $0.5 \times 10^{-5} \mathrm{mg} / \mathrm{L}$ の水溶液の場合には, DCBSについては $23 \%$, その他のタイヤ添加剂については, 6.0 \%以下であった。水溶液 の濃度が $0.5 \times 10^{-5} \mathrm{mg} / \mathrm{L}$ の場合のガラス容器洗浄分をあわせた 全体の回収率については, NDPAが $92 \%$, DPAが $91 \%, \mathrm{CBS}$ が $92 \%$, DCBS が $96 \%$, TBBS が $91 \%$, DTPD が $99 \%$, DPPD が $92 \%$, DMPPD が 103 \%であった。DCBSについては, 疎水性が高く, 試料容器中ではSS もしくは容器内壁に吸着している可能性が高い と報告がある19)。よって, 本研究に扔ける水質試料中の夕イヤ添加 剂の抽出法は, 試料容器は共洗いを行わず, 抽出に際しては, 試料 容器中の全量を分析に供することとした。SS は孔径 $1 \mu \mathrm{m}$ のガラス 繊維ろ紙でろ過をし， ろ紙上の SS 中のタイヤ添加剤の抽出法は, タイヤ粉じん中のタイヤ添加剤の抽出法と同じく, $40{ }^{\circ} \mathrm{C}$ 以下のメ タノール $20 \mathrm{~mL}$ にる 4 時間超音波照射下での抽出とし, ろ液は 固相抽出することとした。固相については, Presep®-Agri を単独 で使用して，20 分間の遠心分離法で脱水し，メタノール $5 \mathrm{~mL}$ で抽 出した後, アセトン $5 \mathrm{~mL}$ で抽出することとした。試料容器等はメ タノールで洗浄し, 各液の窒素ガスパージ濃縮の際には, 壁面をメ タノールで洗い落としながら行い, 各抽出及び洗浄溶液は, あわせ てメタノールで定容, 分析することとした。

分析をするにあたっては，採水してから抽出するまで試料を安定 に保つことが重要である。環境省の化学物質環境実態調査実施の手 引き28)に準拠し, 試料の安定性について確認した。超純水 $50 \mathrm{~mL}$ を $\mathrm{pH} 7$ に調整し, タイヤ添加剂を $50 \mathrm{ng}$ 添加し, (1)冷暗所 $\left(4{ }^{\circ} \mathrm{C}\right)$, (2)室温暗所 $\left(20 \pm 5{ }^{\circ} \mathrm{C}\right)$, (3)室温明所に保存し, 3.3 節で確立した 水質試料中夕イヤ添加剂固相抽出法に打ける, 万液の抽出法と同 様に抽出した。Presep® -Agriに通水, 20 分間の遠心分離法で脱水 し, メタノール $5 \mathrm{~mL}$ で抽出した後, アセトン $5 \mathrm{~mL}$ で抽出し, 試

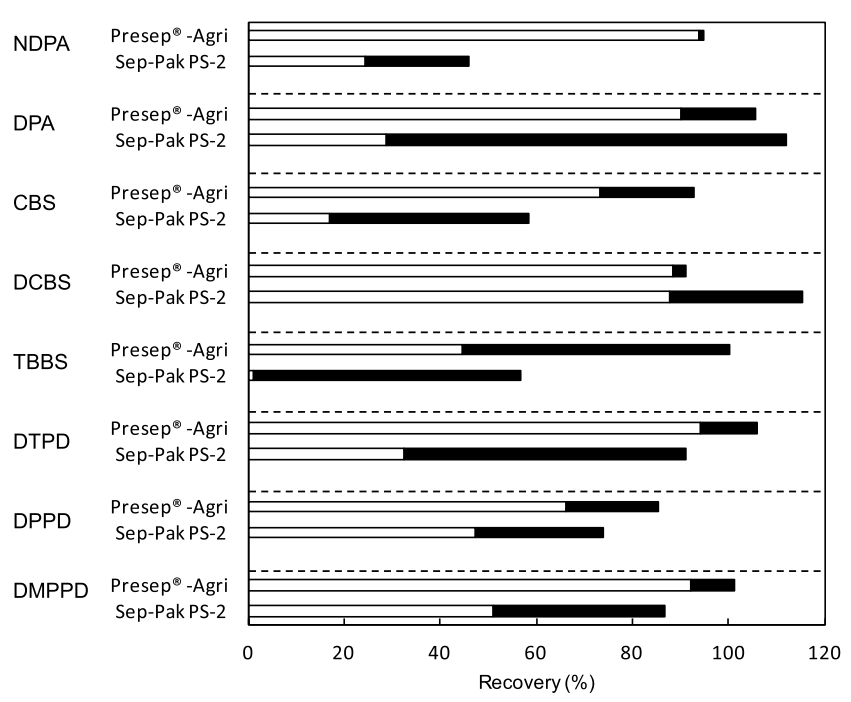

Fig. 7 Changes of recovery rates of tire rubber additives by the extraction methods with $(\square)$ methanol, ( $\square$ ) acetone 
料容器等はメタノールで洗浄し，各抽出及び洗浄溶液は合わせてメ タノールで定容, DPPD-d $1_{10}$ を $50 \mathrm{ng}$ 添加し, LC/MS/MS で定量し た。その結果を Fig. 8 に示す。NDPAは, (1)冷暗所及び(2)室温暗所で, 24 時間で $97 \%$ 以上の安定性があったが, (3)室温明所では 1 時間 で $56 \%$ ，24 時間で $0.1 \%$ に減少した。DPA，DCBS，DPPD 及び DTPD については，(1)冷暗所，(2)室温暗所，(3)室温明所とも， 24 時間で 81 \%以上の安定性が得られた。CBS, TBBS 及び DMPPD は, (1)冷暗所，(2)室温暗所，(3)室温明所とも，1 時間では $86 \%$ 以上の 安定性が得られたが，24 時間での安定性は，(1)冷暗所では CBS は $60 \%$ ，TBBS は $78 \%$ ，DMPPD は $75 \%$ であり，(2)室温暗所及び(3 室温明所での，CBS，TBBS 及び DMPPD の回収率は $34 \%$ 以下と なった。NDPA は光分解する25) ことが知られており，本研究にお いても，光分解性が確認できた。CBS，TBBS，DMPPDについて は，冷所で保存しないと安定でないことが分かった。CBSの(1)冷 暗所での安定性について，4 時間及び 7 時間についても確認したと ころ，4 時間で $89 \% ， 7$ 時間で $77 \%$ であった。以上のことから， 水質試料については, 褐色瓶等遮光できる容器に採取後, すみやか に冷暗所保存し，試料採取後 4 時間以内に抽出しなければならない ことが分かった。

次に，超純水を $\mathrm{pH} 3 ， 5 ， 7 ， 9$ 及び 11 に調整してタイヤ添加剂 を $50 \mathrm{ng}$ 添加し， 1 時間冷暗所に保存した後に $\mathrm{pH} 7$ に調整し，固 相抽出及び LC/MS/MS 定量し，試料の安定性を確認した。その結 果を Fig. 9 に示す。pH7 では，1 時間冷暗所保存条件で，本研究で 対象としたタイヤ添加剤全てについて $82 \%$ 以上の安定性が得られ た。 $\mathrm{pH}$ が低い場合，NDPA，CBS，TBBS 及びDMPPD は分解す る傾向があり， $\mathrm{pH} 3$ では，各夕イヤ添加剤の 1 時間後の安定性は $0.1 \%$ から 66 \%であった。 pH が高い場合は, DMPPD が分解する 傾向にあり, pH11 では, 1 時間後の安定性は 43 \%であった。以上 のことから, 試料は $\mathrm{pH} 6$ ～8であることを確認, 調整してから, すみやかに冷暗所保存及び抽出しなければならないことが分かっ た。

また，河川水の回収率を検討した。 $\mathrm{pH} 7.5$ の河川水 $200 \mathrm{~mL}$ に夕 イヤ添加剤を $1 \mathrm{ng}$ 添加し, 冷暗所保存し 7 時間後にサロゲート内 標準として DPPD-d 10 を $1 \mathrm{ng}$ 添加, 3.3 節で確立した水質試料中夕 イヤ添加剂固相抽出法を用いた。試料容器中の全量を孔径 $1 \mu \mathrm{m}$ の ガラス纎維ろ紙でろ過し， 万紙は， $40{ }^{\circ} \mathrm{C}$ 以下のメタノール $20 \mathrm{~mL}$ による 4 時間超音波照射下での抽出をした。ろ液は Presep®-Agri

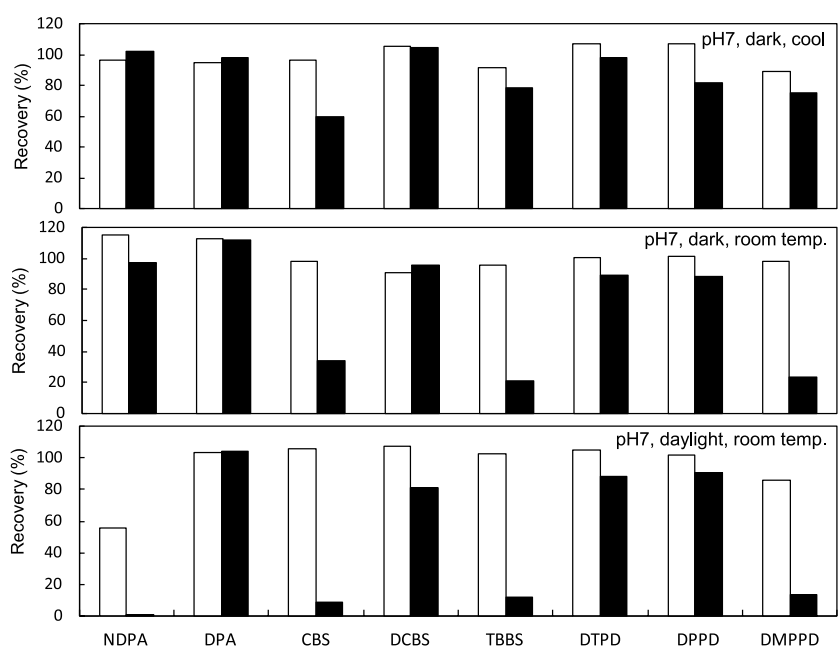

Fig. 8 Stability of tire rubber additives under three preservation conditions for $(\square) 1 \mathrm{~h},(\boldsymbol{\square}) 24 \mathrm{~h}$
に通水，20 分間の遠心分離法で脱水し，メタノール $5 \mathrm{~mL}$ で抽出 した後, アセトン $5 \mathrm{~mL}$ で抽出し, 試料容器等はメタノールで洗 浄, 各抽出及び洗浄溶液は合わせてメタノールで $1 \mathrm{~mL}$ に定容し, LC/MS/MS で定量した。回収率の結果を Table 4 の中欄に示す。本 研究で検討した全てのタイヤ添加剤について，85\%以上の良好な 回収率を示した。また，DPPD-d 10 については絶対検量線法で回収 率を求めたところ, 93 \%であった。各タイヤ添加剤及び DPPD-d 10 の検量線の決定係数 $\left(\mathrm{R}^{2}\right)$ は 0.993 から 0.999 と直線性を示した。

\section{4 底質試料のクリーンナップ法及びピーク強度の安定性}

底質試料中の夕イヤ添加剂の抽出法は, 夕イヤ粉じん中の夕イヤ 添加剂の抽出法と同じく, $40{ }^{\circ} \mathrm{C}$ 以下のメタノール $20 \mathrm{~mL}$ による 4 時間超音波照射下での抽出とし, クリーンナップ法の検討をした。 フロリジルカートリッジカラム及びシリカゲルカートリッジカラ ムにヘキサン $1 \mathrm{~mL}$ でタイヤ添加剤標準品を $5 \mathrm{ng}$ 添加し, へキサ ン $2 \mathrm{~mL}$ で洗浄, 分画溶出し, クリーンアップの検討をした。結果 を Fig.10に示す。シリカゲルカートリッジカラムでは, $20 \%$ アセ トン/ヘキサン $10 \mathrm{~mL}$ (Fr.2) 及び $40 \%$ アヤトン/へキサン $10 \mathrm{~mL}$ (Fr.3）の合計で $82 \%$ 以上が，フロリジルカートリッジカラムでは, ヘキサン $5 \mathrm{~mL}$ (Fr.1) 及び $20 \%$ \%セトン /ヘキサン $10 \mathrm{~mL}$ (Fr.2) で $82 \%$ 以上が溶出でき，そのうちのほとんどが $20 \%$ アセトン /へ キサン $10 \mathrm{~mL}$ (Fr.2) で溶出できた。クリーンナップ時に溶剤の使 用量をより少なくできるフロリジルカートリッジカラムを使用する

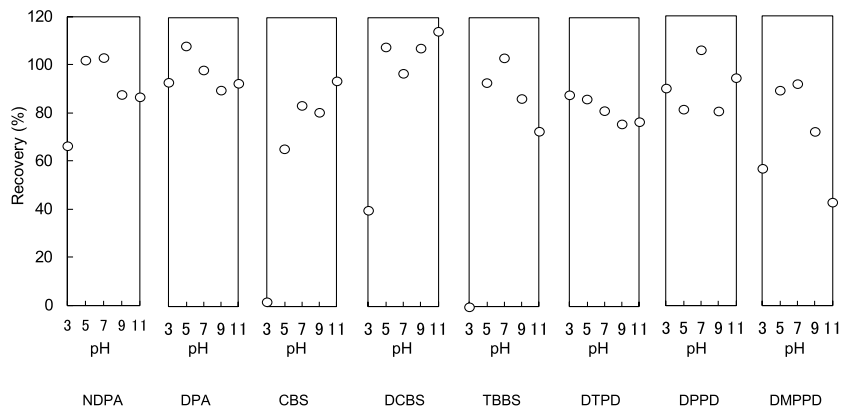

Fig. 9 Effect of $\mathrm{pH}$ on Stability of tire rubber additives at $4{ }^{\circ} \mathrm{C}$ in darkness for $1 \mathrm{~h}$

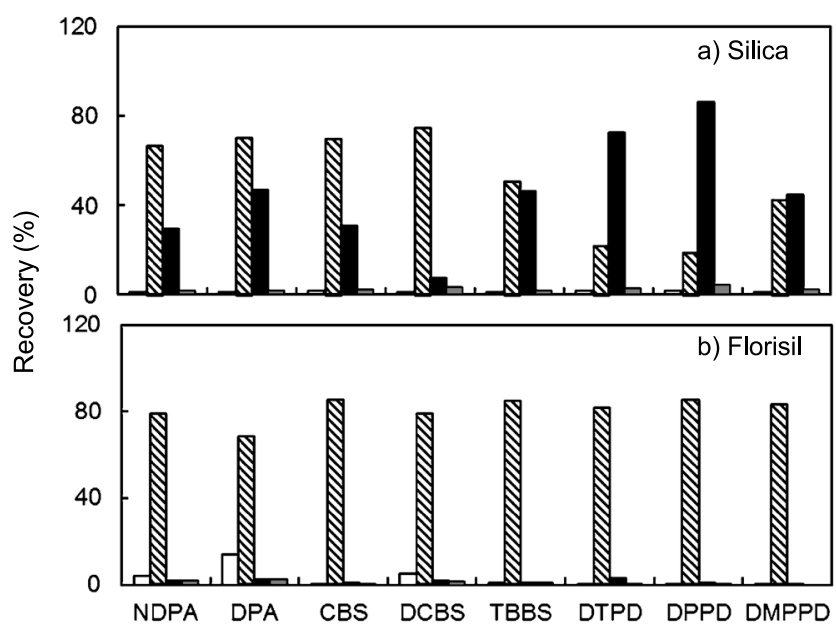

Fig. 10 Elution patterns of tire rubber additives from (a) Silica, (b) Florisil with $(\square)$ Hexane, $(\mathbb{Q})$ acetone/hexane:2/8, (ם) acetone/Hexane:4/6, ( $\square$ ) acetone/Hexane:8/2 
と効率がよいと判断した。

また, 乾泥 $10 \mathrm{~g}$ を $40{ }^{\circ} \mathrm{C}$ 以下のメ夕ノールによる 4 時間照射下 での抽出をし, 20 分間遠心分離後, 上澄み液を窒素ガスパージで $1 \mathrm{~mL}$ に濃縮して, ヘキサン $10 \mathrm{~mL}$ を添加, 無水硫酸ナトリウムで 脱水した試料について，フロリジルカートリッジカラムによるク リーンナップの検討をした。脱水後, ヘキサン $1 \mathrm{~mL}$ に転容し, タ イヤ添加剤標準品を $5 \mathrm{ng}$ 及び DPPD-d $\mathrm{d}_{10}$ を $10 \mathrm{ng}$ 添加してフロリジ ルカートリッジカラムに負荷, ヘキサン $2 \mathrm{~mL}$ で洗浄, 20 \%アセ トンノヘキサン $10 \mathrm{~mL}$ で溶出し, メタノールで $1 \mathrm{~mL}$ に定容した試 料のクロマトグラムと, 脱水後, タイヤ添加剂標準品を $5 \mathrm{ng}$ 及び DPPD-d $_{10}$ を $10 \mathrm{ng}$ 添加し, クリーンナップしないで窒素ガスパー ジ濃縮してメタノールで $1 \mathrm{~mL} に$ 定容した試料のクロマトグラムを 比較した。各試料中のタイヤ添加剤のクロマトグラムを Fig.11に 示す。本実験では, 妨害ピークは認められなかったが, 対象とした タイヤ添加剤についてのクリーンナップしない試料のクロマトグラ ムの面積值は, 標準溶液の 0.2 \%から 36 \%であった。クリーンナッ プした試料の面積值は, 標準溶液の 79 \%から $91 \%$ に回復した。ク リーンナップをしないと, 夾雑物質が対象物質のイオン化を妨げる ので, 正確な定量が出来ないと判断した。また, 本研究において, 試料及び標準液調製はメタノール $100 \%$ で行った。移動相に近い水 とメタノールの混合溶媒で作成した標準液では，特にDCBS 等の 疎水性の高い物質は, 検量線の直線性が保てなかった。標準溶液 (c) $5 \mathrm{ng} / \mathrm{mL}$ にみられるリーデイングは, 強溶出溶媒（メタノール $100 \%$ ）の注入により, 対象成分がカラム先端で十分に保持されな かったために生じたと考えられる。 $5 \mathrm{ng}$ を添加しクリーンナップ しない試料(a)については, メタノール 100 \%でサンプル調製を行っ たが, クリーンナップをしなかったため, 脱水操作後も残留した水 が存在し、リーディングが抑えられたと考えられる。 $5 \mathrm{ng}$ を添加 しクリーンナップした試料（b）については, クリーンナップをし たため, 夾雑物質と一緒に残留した水が除かれ、リーディングした と考えられる。以上の現象は, 10 分の 1 の $0.5 \mathrm{ng}$ を添加した試料 及び 10 分の 1 の濃度の $0.5 \mathrm{ng} / \mathrm{mL}$ 標準溶液で行った場合において も, 同様にみられた。今後, 注入量を $10 \mu \mathrm{L} よ り$ 減らすこと及びグ ラジェント条件等を検討し, 検量線の直線性及び感度等を保ちなが ら、リーディングを防ぐ方法を検討する必要があると考えられる。

次に, 回収率を検討した。乾泥 $10 \mathrm{~g}$ にタイヤ添加剤標準品を $5 \mathrm{ng}$ 及びサロゲート内標準として DPPD-d ${ }_{10}$ を $10 \mathrm{ng}$ 添加し, $40{ }^{\circ} \mathrm{C}$ 以下のメタノールによる 4 時間超音波照射下での抽出をした。脱水, ヘキサン転溶後, フロリジルカートリッジカラムを用い, ヘキサ ン $2 \mathrm{~mL}$ で洗浄, $20 \%$ \%ヤン /ヘキサン $10 \mathrm{~mL}$ で溶出し, メ夕 ノールで $1 \mathrm{~mL} に$ 定容し, LC/MS/MS で定量した。回収率を Table 4 の右欄に示す。本研究で検討した全ての夕イヤ添加剂について, $91 \%$ 以上の良好な回収率を示した。また, DPPD-d 10 については絶 対検量線法で回収率を求めたところ， $82 \%$ であった。各夕イヤ添 加剤及び DPPD-d ${ }_{10}$ の検量線の決定係数 $\left(\mathrm{R}^{2}\right)$ は 0.990 から 1.00 と直線性を示した。以上の結果から, 本研究における底質試料中の タイヤ添加剤の抽出法は, $40{ }^{\circ} \mathrm{C}$ 以下のメタノールによる超音波照 射下での抽出, 脱水後にクリーンアップをすることとした。フロリ ジルカートリッジカラムに試料を負荷後, ヘキサン $2 \mathrm{~mL}$ で洗浄, 20 \%アセトン/ヘキサン $10 \mathrm{~mL}$ で溶出してクリーンアップし, メ タノール転溶, LC/MS/MS で定量することとした。

\section{5 測定方法の定量下限}

操作ブランク試料の測定で得られるシグナル／ノイズ $(\mathrm{SN})$ 比 に基づいて測定方法の定量下限值 $(\mathrm{QL})$ を求めた。操作ブランクは, 大気粉じんについては, 石英繊維ろ紙上にサロゲート内標準 DPPD- (a ) Sample solution without clean up
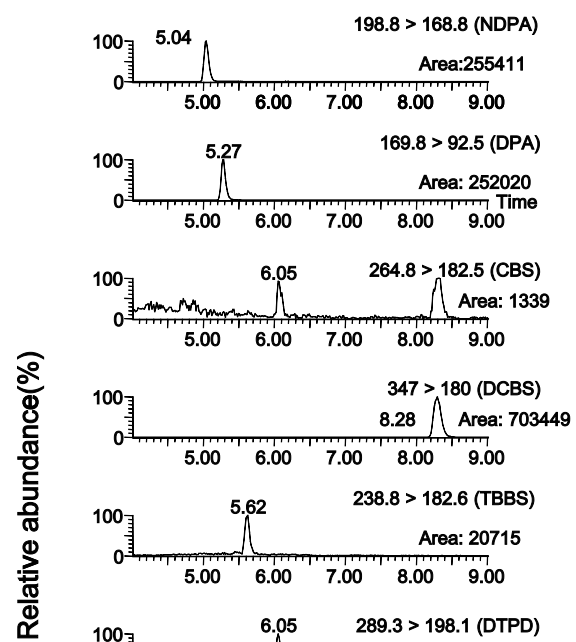
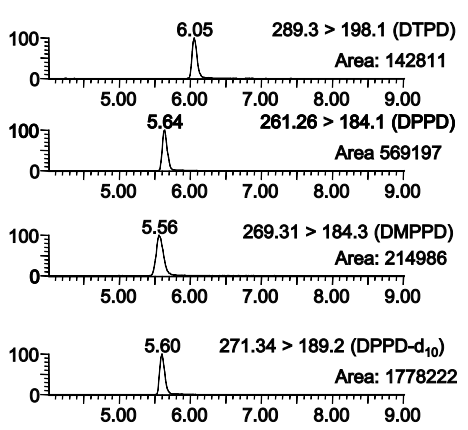

(b) Sample solution with clean up
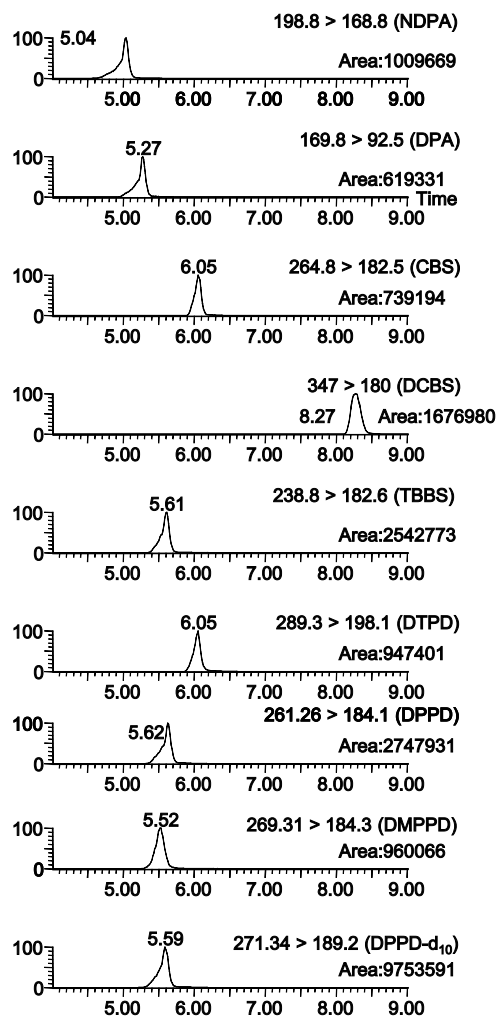

(c) $5 \mathrm{ng} / \mathrm{mL}$ standard solution
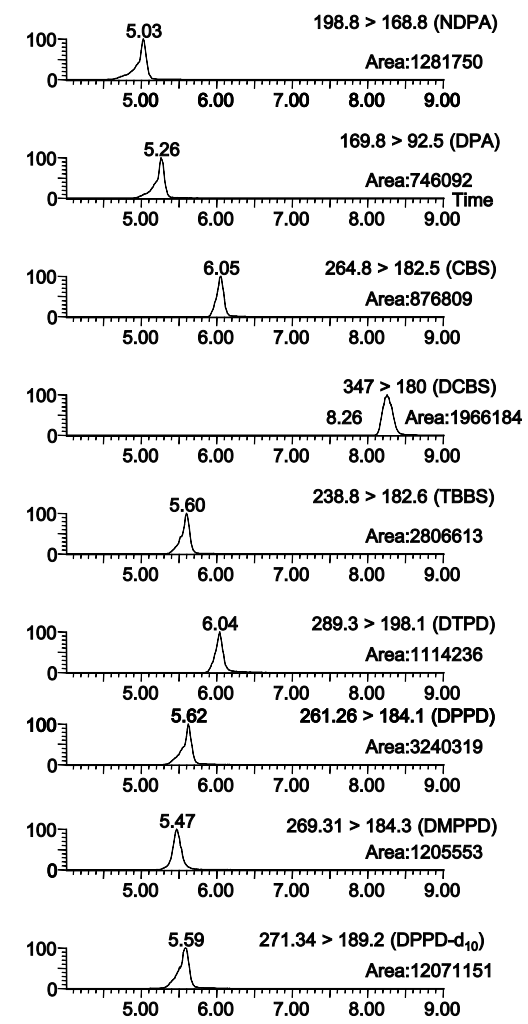

Fig. $11 \mathrm{LC} / \mathrm{MS} / \mathrm{MS}$ chromatograms of recovered $5 \mathrm{ng}$ tire rubber additives from sediment samples (a)without clean up, (b)with clean up, and (c) $5 \mathrm{ng} / \mathrm{mL}$ standard solution 
$\mathrm{d}_{10}$ を $1 \mathrm{ng}$ 添加し，3.1節において確立したタイヤ粉じん中の夕イ ヤ添加剤の抽出法, $40{ }^{\circ} \mathrm{C}$ 以下のメ夕ノール $20 \mathrm{~mL}$ による 4 時間超 音波照射下での抽出をし，LC/MS/MS で定量した。水質試料につ いては，超純水 $200 \mathrm{~mL}$ にサロゲート内標準 DPPD-d $\mathrm{d}_{10}$ を $1 \mathrm{ng}$ 添加 し, 3.3 節で確立した水質試料中夕イヤ添加剂固相抽出法を用い た。試料容器中の全量を孔径 $1 \mu \mathrm{m}$ のガラス繊維ろ紙でろ過し, ろ 紙は, $40{ }^{\circ} \mathrm{C}$ 以下のメ夕ノール $20 \mathrm{~mL}$ による 4 時間超音波照射下で の抽出をした。ろ液は Presep®-Agri に通水，20 分間の遠心分離法 で脱水し, メタノール $5 \mathrm{~mL}$ で抽出した後, アセトン $5 \mathrm{~mL} て ゙$ 抽出 し, 試料容器等はメタノールで洗浄, 各抽出及び洗浄溶液は合わせ てメタノールで定容し，LC/MS/MS で定量した。底質試料につい ては，遠沈管内にサロゲート内標準 DPPD-d $\mathrm{d}_{10}$ を $10 \mathrm{ng}$ 添加し，3.4 節で確立した底質試料中夕イヤ添加剂抽出法を用いた。 $40{ }^{\circ} \mathrm{C}$ 以下 のメタノールによる 4 時間超音波照射下での抽出をし, 脱水, へキ サン転溶後，フロリジルカートリッジカラムによるクリーンナッ プをした。ヘキサン $2 \mathrm{~mL}$ で洗浄， $20 \%$ アセトン/ヘキサン $10 \mathrm{~mL}$ で溶出し，メタノールで $1 \mathrm{~mL}$ に定容して LC/MS/MS で定量し た。得られた操作ブランクのピークについて, 対象物質が溶出す る位置での $\mathrm{SN}$ 比の 10 倍に相当するピーク強度を定量下限值とし た。使用した検量線の決定係数 $\left(\mathrm{R}^{2}\right)$, 定量下限值及び本測定方法 によって分析した大気粉じん，河川水，底質試料の濃度を Table 5 に示す。検量線の $\mathrm{R}^{2}$ は 0.985 から 0.998 の良好な直線性を示した。 大気粉じんでは, DPAが $0.0003 \mathrm{ng} / \mathrm{m}^{3}, \mathrm{CBS}$ が $0.0008 \mathrm{ng} / \mathrm{m}^{3}$, DCBS が $0.0010 \mathrm{ng} / \mathrm{m}^{3}$, TBBS が $0.0022 \mathrm{ng} / \mathrm{m}^{3}$, DPPD が, $0.0002 \mathrm{ng} / \mathrm{m}^{3}$, DMPPD が, $0.0012 \mathrm{ng} / \mathrm{m}^{3}$ 検出され, 河川水では, CBSが $1.6 \mathrm{ng} / \mathrm{L}$, DCBS が $0.10 \mathrm{ng} / \mathrm{L}$, TBBSが $0.29 \mathrm{ng} / \mathrm{L}$ 検出され, 底質試料では NDPA0. $017 \mathrm{ng} / \mathrm{g}$ が, DPA が $0.017 \mathrm{ng} / \mathrm{g}$, DCBS $0.034 \mathrm{ng} / \mathrm{g}$ 及び DMPPD が $0.35 \mathrm{ng} / \mathrm{g}$ 検出された。

Table 4 Recovery of tire rubber additives in this study

\begin{tabular}{|c|c|c|c|c|c|c|c|c|c|}
\hline \multirow[t]{2}{*}{ Tire rubber additives } & \multicolumn{3}{|c|}{$\begin{array}{l}\text { Ing of tire rubber } \\
\text { additives in } \\
\text { Quartzair filter }\end{array}$} & \multicolumn{3}{|c|}{$\begin{array}{l}\text { Ing of tire rubber } \\
\text { additives in } \\
\text { River Water }\end{array}$} & \multicolumn{3}{|c|}{$\begin{array}{l}\text { 5ng of tire rubber } \\
\text { additives in } \\
\text { Sediment" }\end{array}$} \\
\hline & $\begin{array}{c}\text { Recovery } \\
(\%) \\
\end{array}$ & $\begin{array}{l}\text { RSD } \\
(\%)\end{array}$ & $\mathrm{R}^{2}$ & $\begin{array}{c}\text { Recovery } \cdots \\
(\%) \\
\end{array}$ & $\begin{array}{l}\text { RSD } \\
(\%)\end{array}$ & $\mathrm{R}^{2}$ & $\begin{array}{c}\text { Recovery } \cdots \\
(\%)\end{array}$ & $\begin{array}{l}\text { RSD } \\
(\%)\end{array}$ & $\mathrm{R}^{2}$ \\
\hline NDPA & 94 & 7.5 & 0.994 & 90 & 4.1 & 0.998 & 98 & 9.5 & 1.00 \\
\hline DPA & 97 & 5.0 & 0.995 & 90 & 3.7 & 0.995 & 106 & 6.6 & 0.995 \\
\hline CBS & 95 & 6.9 & 1.00 & 89 & 7.0 & 0.999 & 91 & 5.8 & 0.999 \\
\hline DCBS & 92 & 6.7 & 0.994 & 90 & 3.5 & 0.998 & 92 & 7.4 & 0.997 \\
\hline TBBS & 92 & 5.7 & 0.998 & 88 & 4.3 & 0.999 & 93 & 6.6 & 0.999 \\
\hline DTPD & 96 & 5.8 & 0.994 & 89 & 4.3 & 0.997 & 91 & 6.1 & 1.00 \\
\hline DPPD & 98 & 7.5 & 0.998 & 85 & 3.9 & 0.996 & 97 & 8.7 & 1.00 \\
\hline DMPPD & 95 & 6.2 & 0.998 & 89 & 5.5 & 0.993 & 95 & 7.1 & 0.990 \\
\hline DPPD- $\mathrm{d}_{10} \cdots \cdots$ & 92 & 10.2 & 0.991 & 93 & 5.9 & 0.996 & 82 & 7.0 & 1.00 \\
\hline
\end{tabular}

* Calibration carve coefficient in the range of $0.05,0.1,0.2,0.5,1,2 \mathrm{ng} / \mathrm{mL}$ standard solution

** Calibration carve coefficient in the range of $0.1,0.2,0.5,1,2,5,10 \mathrm{ng} / \mathrm{mL}$ standard solution.

**** Absolute calibration method

Table 5 Quantification limits in the measurements of tire rubber additives in this study

\begin{tabular}{|c|c|c|c|c|c|c|c|}
\hline \multirow[t]{4}{*}{ Tire rubber additives } & \multirow{4}{*}{$\begin{array}{c}\text { Calibration } \\
\text { carve } \\
\text { coefficient } \\
\left(\mathrm{R}^{2}\right)^{*}\end{array}$} & \multicolumn{2}{|c|}{$\begin{array}{c}\text { Atmospheric particulates } \\
/ 1144.4 \mathrm{~m}^{3} \\
\end{array}$} & \multicolumn{2}{|c|}{$\begin{array}{c}\text { River water } \\
/ 200 \mathrm{~mL}\end{array}$} & \multicolumn{2}{|c|}{$\begin{array}{c}\text { Sediment } \\
/ 10 \mathrm{~g}\end{array}$} \\
\hline & & & ivironmental & & vironmental & & nvironmental \\
\hline & & QL & Sample & QL & Sample & QL & Sample \\
\hline & & $\left(\mathrm{ng} / \mathrm{m}^{3}\right)$ & $\left(\mathrm{ng} / \mathrm{m}^{3}\right)$ & $(\mathrm{ng} / \mathrm{L})$ & $(\mathrm{ng} / \mathrm{L})$ & $(\mathrm{ng} / \mathrm{g})$ & $(\mathrm{ng} / \mathrm{g})$ \\
\hline NDPA & 0.996 & 0.0001 & $<0.0001$ & 0.06 & $<0.06$ & 0.007 & 0.017 \\
\hline DPA & 0.994 & 0.0002 & 0.0003 & 0.3 & $<0.3$ & 0.008 & 0.017 \\
\hline CBS & 0.987 & 0.0001 & 0.0008 & 0.2 & 1.6 & 0.008 & $<0.008$ \\
\hline DCBS & 0.985 & 0.0001 & 0.0010 & 0.06 & 0.10 & 0.007 & 0.034 \\
\hline TBBS & 0.995 & 0.0001 & 0.0022 & 0.06 & 0.29 & 0.009 & $<0.009$ \\
\hline DTPD & 0.998 & 0.0001 & $<0.0001$ & 0.04 & $<0.04$ & 0.0008 & $<0.0008$ \\
\hline DPPD & 0.998 & 0.0001 & 0.0002 & 0.05 & $<0.05$ & 0.0009 & $<0.0009$ \\
\hline DMPPD & 0.995 & 0.0002 & 0.0012 & 0.08 & $<0.08$ & 0.01 & 0.35 \\
\hline
\end{tabular}

\section{4. まとめ}

有害性が懸念され，環境中で検出されると考えられる化管法対象 等の夕イヤ添加剂について, 大気, 水質及び底質試料の一斉分析法 の検討を行い, 試料の性状や分析時の諸条件による夕イヤ添加剂の 安定性及び抽出効率の影響について明らかにした。

1 ）タイヤ粉じん中タイヤ添加剤の抽出方法は, $40{ }^{\circ} \mathrm{C}$ 以下に扔け る 4 時間の超音波照射下での抽出とし, タイヤからの抽出溶媒はメ タノールが抽出効率が良いということがわかった。

2 ）大気試料からの添加回収試験では, 検討した各試験方法では充 分な回収率が得られなかったが，模擬夕イヤ粉じん試料及び捕集済 み大気粉じん試料を 4 日間, 環境大気を通気した結果, 対象とした タイヤ添加剤については，87\%以上の回収率を得ることが出来た。 粉じん粒子の表面に付着していたり，ガス状のいわゆる遊離態の添 加剂は分析できないが, タイヤ摩耗片に溶け込んでいる粉じん中の タイヤ添加剤は粉じん中にある際には直接空気に触れないため, 分 解されにくく，分析が可能であることが分かった。

3 ) 水質試料からの固相抽出の際, 脱水方法に窒素ガスパージを使 うと, タイヤ添加剤が分解する可能性があり, 脱水方法は, 遠心 分離が良いことが分かった。固相は Presep®-Agri を使用し, メ夕 ノール及びアセトンで溶出, ガラス容器へ吸着したタイヤ添加剂 は, メタノールで洗浄し, 固相抽出したものと合わせて定容したと ころ, 本研究で検討したタイヤ添加剤については, 超純水において, 91 \%以上の良好な回収率を示した。

4 ) 水質試料の安定性について確認したところ, 褐色瓶等遮光でき る容器に採取し, $\mathrm{pH} 6$ ～8であることを確認, 調整してから, す みやかに冷暗所保存し, 試料採取後 4 時間以内に抽出しなければな らないことが分かった。 pH7. 5 の河川水を冷暗所に保存し， 7 時間 後に抽出したところ, 本研究で検討したタイヤ添加剤については, $85 \%$ 以上の良好な回収率を示した。

5 ）底質試料中の夕イヤ添加剤のクリーンアップ法を検討したとこ ろ，フロリジルカートリッジカラムを用いて $20 \%$ \%セトン/へキ サン $10 \mathrm{~mL}$ で溶出する方法により, 夾雑物質によるピーク強度の 低下を防ぐことができ，本研究で検討したタイヤ添加剤について， $91 \%$ 以上の回収率を得ることが出来た。

\section{謝 辞}

廃タイヤリサイクル微粉ゴムを提供していただいた寿産業（株） 鈴木俊幸氏に厚く謝意を表する。

LC/MS/MSに扔けるタイヤ添加剤の分析条件等について, 指導, 助言していただいた神奈川県環境科学センターの長谷川敦子氏に厚 く謝意を表する。

\section{要 約}

近年，化管法対象等のタイヤ添加剤の環境影響が懸念されてい る。そのため, タイヤ添加剤の環境中における挙動について明らか にすることは重要である。本研究では, 環境中の夕イヤ添加剤の一 斉分析法の検討を行い, その安定性と抽出効率に対する諸条件の影 響について明らかにした。タイヤ粉じん中タイヤ添加剤の抽出方法 を検討したところ, $40{ }^{\circ} \mathrm{C}$ 以下の 4 時間超音波抽出が効率良いこと が分かった。大気粉じん試料を 4 日間，環境大気を通気した結果， 対象としたタイヤ添加剤については，87\%以上の回収率を得るこ とが出来た。水質試料の固相抽出法におけるカートリッジの脱水方 法を検討したところ, 窒素ガスパージと比較して遠心分離の効率が 
良かった。また，水質試料については $\mathrm{pH} 6$ ～8であることを確認， 調整してからすみやかに冷暗所保存し, 試料採取後 4 時間以内に抽 出する必要があることが分かった。超純水及び河川水に打ける夕イ ヤ添加剂の回収率は，85\%以上であった。底質試料は，フロリジ ルカートリッジでクリーンナップすることで, タイヤ添加剤のピー ク強度の低下を防ぐことができ，本研究で検討したタイヤ添加片に ついて, $91 \%$ 以上の回収率が得られた。

\section{文 献}

1）土岐真一, 國見均: 道路近傍における夕イヤ磨耗粉じんの計測 と排出係数の推計，大気環境学会誌，41，144-163（2006）

2) 佐藤幸生, 熊田英峰, 藤原祺多夫 : 都市大気粉じんの起源物質 から水中へ溶出する化学物質の GC/MS による検索，第50回日 本分析化学会念会講演要旨集, 104（2001）

3）山口孝子, 山崎裕康, 山内あい子, 垣内靖男：道路近傍におけ る浮遊粒子状物質中のタイヤトレッド摩耗粉じん及びゴム添加 剤の分析, 衛生化学, 41, 155-162（2001）

4) Kumata, H., Sanada, Y., Takada, H. and Ueno, T.: Historical trends of N-cyclohexyl-2-benzothiazolamine, 2-(4-morpholinyl)benzothiazole and other anthropogenic contaminants in the urban reservoir sediment core. Environ. Sci. Technol., 34, 246-253 (2000)

5）坂本和彦, 広田祐二, 根津豊彦, 坪田美佐, 君島克憲, 奥山正喜: 大型車や小型車の道路走行により発生するタイヤ摩耗粉じんの 大気粒子状物質への寄与, エアゾル研究，14，242-247 (1999)

6) Spies, R.B., Andresen, B.D. and Rice, D.W. Jr: Benzthiazoles in estuarine sediments as indicators of street runoff, Nature, 327, 697-699 (1987)

7) Wik, A: Toxic components leaching from tire rubber, Bulletin of environmental Cntamination and Toxicology, 79, 114-119 (2007)

8）環境省告示：微小粒子状物質による大気の污染に係る環境基準 について，平成21年 9 月 9 日 環告33

9）経済産業省, 環境省: 特定化学物質の環境への排出量の把握等 及び管理の改善の促進に関する法律, 平成 11 年 7 月 13 日法律第 86 号

10）環境省環境保健部環境安全課：化学物質ファクトシート2011年 版, http://ceis.sppd.ne.jp/fs2011/factsheet/top1.html

11）環境省環境保健部環境安全課：PRTR インフォメーション広場, http://www.env.go.jp/chemi/prtr/result/index.html

12）環境省環境保健部環境リスク評価室：生態影響試験結果一覧 (平成24年 3 月版), http://www.env.go.jp/chemi/sesaku/seitai. html
13）環境省環境保健部環境リスク評価室：化学物質の環境リスク 評価第 8 巻 (2010), http://www.env.go.jp/chemi/report/h2201/pdf/chpt2/2-2-2-25.pdf, http://www.env.go.jp/chemi/report/ h22-01/pdf/chpt2/2-2-2-33.pdf

14）環境省環境保健部環境リスク評価室：化学物質の環境リスク 評価第 5 巻 (2006), http://www.env.go.jp/chemi/report/h1812/pdf/chpt1/1-2-2-17.pdf, http://www.env.go.jp/chemi/report/ h18-12/pdf/chpt2/2-2-2-18.pdf

15）環境省環境保健部環境リスク評価室：化学物質の環境リスク評 価第 4 巻 (2005), http://www.env.go.jp/chemi/report/h17-21/ pdf/chpt1/1-2-2-10.pdf

16）（独）製品評価技術基盤機構：化学物質の初期リスク評 価 書 (2005), http://www.safe.nite.go.jp/risk/files/pdf_ hyoukasyo/282riskdoc.pdf, pp 9-14

17) OECD: SIDS Initial assessment report (2004), http://webnet. oecd.org/HPV/ui/Default.aspx

18) Government of Canada: The Government of Canada "Challenge" for chemical substances that are a high priority for action (1999), http://www.chemicalsubstanceschimiques.gc.ca/challenge-defi/ batch-lot-11/index-eng.php

19）環境省環境保健部環境安全課：平成20年度化学物質分析法開発 調査報告書, pp 100-116（2008）

20）環境省環境保健部環境安全課：平成18年度化学物質分析法開発 調査報告書, pp 842-857（2006）

21）環境省環境保健部環境安全課：平成16年度化学物質分析法開発 調査報告書, pp 31-67，147-156（2004）

22）環境省環境保健部環境安全課：平成15年度化学物質分析法開発 調査報告書, pp 247-256（2003）

23）環境省環境保健部環境安全課：平成14年度化学物質分析法開発 調查報告書, pp 29-47（2002）

24）環境省環境保健部環境安全課：平成 9 年度化学物質分析法開発 調査報告書, pp 153-341（1997）

25）環境省環境保健部環境安全課：平成元年度化学物質分析法開発 調査報告書, pp 64-72（1989）

26) Barnes, K.A., Castle, L., Damant, A.P., Read, W.A. and Speck, D.R.: Development and application of an LC-MS method to determine possible migration of mercaptobenzothiazole, benzothiazole and related vulcanization, Food Addit. Contam., 20, 195-205 (2003)

27) Gradwell, M.H.S. and Mcgill, W.J.: The thermal decomposition of sulfenamide accelerators, J. Appl. Polym. Sci., 51, 169-176 (1994)

28）環境省環境保健部環境安全課：化学物質環境実態調査実施の手 引き (平成20年度版)，pp116-119，126，127（2009） 